\title{
A CONTRIBUIÇÃO PROPOSITIVA DA QUADRA URBANA NO CONTEXTO DA REVISÃO DO PLANO DIRETOR DE JOÃO PESSOA-PB
}

\author{
LA CONTRIBUCIÓN PROPOSITIVA DE LA CUADRA URBANA EN EL CONTEXTO DE LA REVISIÓN DEL PLAN \\ DIRECCIÓN DE JOÃO PESSOA-PB
}

THE PROPOSITIVE CONTRIBUTION OF THE URBAN BLOCK IN THE CONTEXT OF THE REVISION OF THE PLAN DIRECTOR OF JOÃO PESSOA-PB

\section{SUASSUNA, MARCO1}

Arquiteto, Mestre (Unipê e Unifacisa), e-mail: marcosuassuna@gmail.com

\section{LACERDA JR, LUCIO²}

Graduado em Arquitetura e Urbanismo (Centro Universitário de João Pessoa - Unipê), e-mail: Iuciojr@outlook.com

\section{RESUMO}

O Plano Diretor de João Pessoa-PB está sendo revisado, mas com tímida participação da sociedade civil. Entre os inúmeros temas a serem debatidos, as transformações nas escalas dos bairros merecem uma preocupação dos gestores públicos, sobretudo a verticalização sem planejamento com impactos socioespaciais na vida dos moradores. Sobre esse tema, como reflexão e investigação espacial, foi escolhido o bairro dos Bancários, localizado na região sul, ainda com margem para ser adensado, e inserido na Zona Adensável não Prioritária, próximo de duas instituições de ensino superior importantes (Universidade Federal da Paraíba e Centro Universitário de João Pessoa-PB), de serviços bancários, centros de compras, escolas, creches, praças, porém concentrados prioritariamente na avenida principal do bairro Avenida Emp. João Rodrigues Alves. A dinâmica urbana do bairro vem sendo transformada rapidamente, o que deriva do processo de verticalização e do intenso interesse do mercado imobiliário em especular o solo seguido da mercantilização do espaço sem regulação do poder público. Tal realidade é comum em vários bairros da capital paraibana, com impactos danosos ora já percebidos ou com tendência de serem acentuados, tais como congestionamento no tráfego, monofuncionalismo, comprometimento da ventilação natural, relação de negação entre as edificações e os espaços públicos, e aumento da sensação de insegurança nas quadras mais distantes das vias principais pela ausência de movimento nas calçadas.

PALAVRAS-CHAVE: plano diretor; bairro; quadra híbrida.

\section{RESUMEN}

El Plan Director de João Pessoa-PB está siendo revisado, con poca participación de la sociedad civil. Entre los innumerables temas a ser debatidos, uma de las más importantes es las transformaciones y escalas de los barrios, este asunto merece la preocupación de los gestores públicos, sobre todo em lo que se refiere a la verticalización sin planificación con impactos sócio-espaciales en la vida de los pobladores. Para este tema, sobre reflexión en la investigación espacial fue escogido el Barrio Bancários, localizada em la región Sur, aun con áreas para densificar, la qual está inserido en la zona de densificación próximo de dos instituciones educativas importantes (Universidade Federal da Paraíba y Centro Universitário de João pessoa) en este sector encontramos servicios bancarios, centros de compras, escuelas, guarderías y plazas. Estas actividades estan concentrados prioritariamente en la avenida principal del barrio, conocida como Avenida Emp. Juan Rodrigues Alves. La dinámica urbana del barrio viene siendo transformado rápidamente, derivado del proceso de verticalización y del intenso interés del mercado inmobiliario, caracterizando la especulación del suelo, seguido de la mercantilización del espacio sin regulación del poder público. Esta realidad es común en varios barrios de la capital paraibana, con impactos dañinos ya percibidos o con tendencia a ser acentuados tales como congestión en el tráfico, monofuncionalismo, comprometimiento de la ventilación natural, relación de negación entre las edificaciones y los espacios públicos, y aumento en la sensación de inseguridad en el vencindario, sobre todo en las cuadras más distantes de las vías principales por la ausencia de movimento de personas en las aceras.

PALABRAS CLAVE: plan director; vecindario; la cuadra híbrida.

\section{ABSTRACT}

The Master Plan of João Pessoa-PB is being revised, but with timid participation of civil society. Among the many issues to be discussed, the transformations in the neighborhood scales deserves a concern of the public managers, especially the unplanned verticalization with socio-spatial impacts in the life of the residents. About this matter, as a reflection and spatial investigation, the neighborhood of the Banks was chosen, located in the South region, still with margin to be densified, and inserted in the Non-Priority Zone, near two important higher education institutions (Federal University of Paraiba and Centro Universitário de João Pessoa-PB), banking services, shopping centers, schools, day care centers, squares, primarily concentrated on the main avenue of Avenida Emp. João Rodrigues Alves neighborhood. The urban landscape of the neighborhood has been transformed quickly, derived from the process of verticalization without planning and the intense interest of the real estate market in speculating the soil and the commercialization of the space. This reality is common in several districts of the capital of Paraiba, with harmful impacts now perceived or with a tendency to be accentuated such as traffic congestion, monofunctionalism, natural ventilation impairment, a relationship of denial between buildings and public spaces, and sense of insecurity.

KEYWORDS: master plan; neighborhood; hybrid block. 


\title{
1 INTRODUÇÃO
}

No dia 05 de outubro de 2017, no teatro de Arena do Espaço Cultural da capital paraibana, uma palestra do ex-prefeito de São Paulo Fernando Haddad, encerrava o Seminário Cidades Democráticas realizado pelo Fórum Plano Diretor Participativo (FPDP), organismo que conta com mais de 30 organizações da cidade de João Pessoa, incluindo movimentos sociais, entidades de classe, mandatos parlamentares, sindicatos, centros comunitários, instituições de ensino, redes, coletivos e organizações não-governamentais, conforme descreve o Vereador Tibério Limeira (PSB). O FPDP convidou formalmente gestores da prefeitura, que não compareceram ao evento. A sociedade civil permanece questionando o fato do Plano Diretor (PD) de João Pessoa-PB estar sendo revisado por uma comissão interna do poder executivo, contrariando noções básicas da gestão democrática contidas no Estatuto da Cidade (Lei Federal 10.257/2001). Até o encerramento deste texto, passados oito meses do referido Seminário, a prefeitura vem apenas sinalizando que apresentará em breve os resultados dos trabalhos elaborados pela comissão interna de técnicos, para receber críticas e sugestões da sociedade civil, fato ainda não ocorrido, o que é preocupante, pois o prazo legal se encerra no final deste ano de 2018. Tal postura hermética não está compatível com o processo participativo de revisão do PD de qualquer cidade. Na ocasião pós-evento, escrevi nas redes sociais:

\begin{abstract}
$\mathrm{Na}$ palestra de Haddad (um político e ex-prefeito da maior cidade brasileira), noções ou conceitos de ordenamento espacial, calçadas animadas, bairros saudáveis, térreos com comércios, relação com setor privado, mobilidade urbana, espaços públicos foram lucidamente mencionados. Sabemos que o êxito do ex-prefeito deve muito às assessorias fundamentais de arquitetos e urbanistas no seu governo, isso é fato que merece o registro. Lembro a participação de Fernando de Melo Franco, um arquiteto e urbanista com experiência prática em projetos urbanos e arquitetônicos, co-fundador do escritório paulista MMBB, e Secretário de Desenvolvimento Urbano (2012-2016) na gestão municipal da capital paulista. Por isso que agora, é hora de apresentarmos nas discussões para a população, estudos preliminares de densidades habitacionais por bairros, estudos de mobilidade urbana e demais aspectos espaciais que ilustram de forma mais compreensível o fato real urbano para apoiar o entendimento das pessoas sobre o significado do Plano Diretor, que é uma lei municipal que incorporará os caminhos como a cidade deve crescer de forma mais justa e sustentável para os próximos 10 anos. Acho que nesse momento a sociedade precisará muito dos arquitetos e urbanistas, geógrafos e outros técnicos para auxiliar nessa etapa importante. É o momento das universidades apresentarem seus repertórios de estudos da cidade para auxiliar no diagnóstico das principais problemáticas e potencialidades como pressuposto para a formulação das diretrizes do PD. (LIMA, postagem no Facebook, de 06-10-2017).
\end{abstract}

$\mathrm{Na}$ condição do não diálogo da prefeitura com a população, a intenção do texto nas redes sociais foi de externar uma inquietação sobre a importância do PD na vida da comunidade, e assim tentar sensibilizar os participantes do fórum, na mudança para outro formato que fosse mais próximo do entendimento do leigo, já que o formato apresentado em palestras e audiências públicas quase sempre é técnico e distante da realidade do povo. Obviamente, tudo seria mais fácil se o poder executivo, na figura do prefeito, cumprisse a determinação legal de gestão democrática, construindo um processo participativo na revisão do PD, convocando a sociedade civil a colaborar com o planejamento urbano do município de João Pessoa-PB, e disponibilizando sua base de dados democraticamente para a elaboração de oficinas participativas, cartilhas e demais instrumentos de debate público, descentralizados por toda a cidade. Embora pareça utópico, São Paulo, Jundiaí, Jandira - SP, dentre muitas outras cidades, fizeram isso.

$\mathrm{Na}$ medida em que essa abertura ao diálogo não ocorreu, e sabendo dos riscos que prováveis relações tendenciosas entre o poder executivo e setores hegemônicos do capital imobiliário podem provocar na desigualdade desenvolvimento urbano, como atitude proativa, apresentamos para o grupo do FPDP algumas ideias e contribuições que podem ser incorporadas nesta etapa da revisão do Plano Diretor. É um estudo propositivo ainda em construção, mas que já anuncia algumas diretrizes para serem amadurecidas com uma discussão mais ampla, transversal e multidisciplinar entre a população, técnicos e gestores da cidade. As reflexões se apoiam na literatura especializada de cidade para pessoas (Gehl, Jacobs, Speck, Campos Filho, dentre outros), em vivências como colaborador arquiteto e urbanista em gestões municipais, com passagens nas Secretarias Municipais da Habitação e de Planejamento Urbano, de 2007 a 2010, em 2013, como morador do bairro e como cidadão preocupado com a qualidade de vida desta e das futuras gerações da capital paraibana. Para tal, apresentamos um instrumento que consideramos fundamental no processo de planejamento urbano. O Plano Diretor de Bairro (PDB), conceito já defendido por Campos Filho (2013): 
(...) por isso, vamos defender aqui o que chamamos de Plano de Bairro ou Plano Diretor de Bairro. É um modo novo de colocar você, cidadão, no centro da discussão do Plano Diretor. É justamente um jeito de colocá-lo como ponto de partida no pensar a qualidade de vida urbana, no que ela tem de dependência em relação à organização do espaço de uma cidade. (CAMPOS FILHO, 2003, p. 10)

Figuras 01,02 e 03: Localização do objeto de estudo na escala da cidade, do bairro e da quadra.
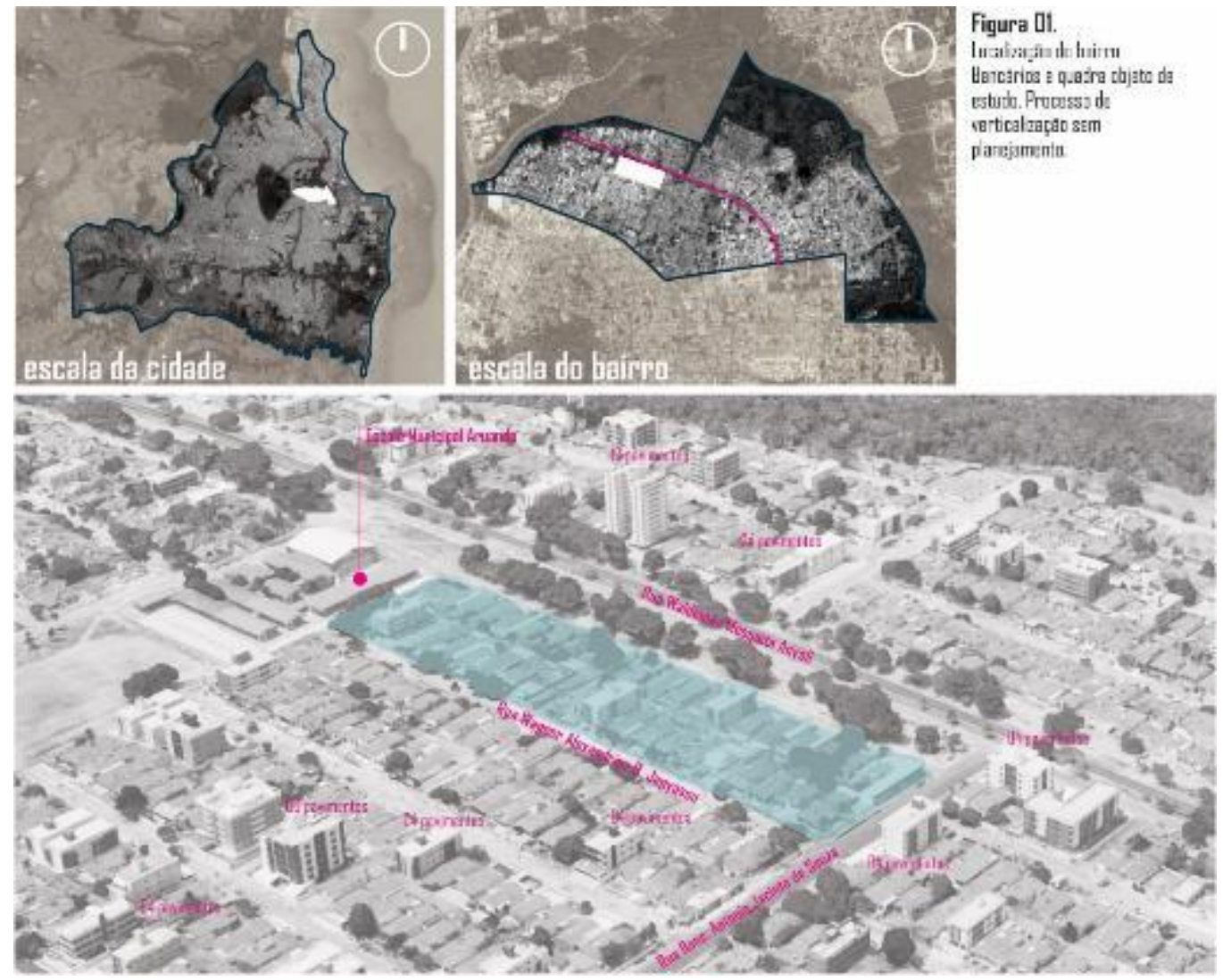

Fonte: Urbanicidade ${ }^{3}$

Como reflexão e investigação espacial, foi escolhido o bairro dos Bancários, localizado na região sul, ainda com margem para adensamento, com franco crescimento da população urbana desde anos 2000, próximo de duas instituições de ensino superior importantes (Universidade Federal da Paraíba e Centro Universitário de João Pessoa-PB), de serviços bancários, centros de compras, escolas, creches, praças e atualmente em construção uma Unidade de Pronto Atendimento (UPA). A maior parte desses equipamentos urbanos se encontra na Avenida Emp. João Rodrigues Alves. A dinâmica urbana do bairro vem sendo transformado rapidamente, derivado do processo de verticalização sem planejamento e do intenso interesse do mercado imobiliário em especular o solo e da mercantilização do espaço.

Utiliza-se como estratégia e método, o estudo de uma quadra, seus usos, impactos e transformações desde a gênese da ocupação até os dias atuais, e a tendência futura, caso não haja nenhuma providência mitigadora ou reguladora do seu ordenamento urbano. $O$ caso da quadra em estudo é um exemplo local com reproduções semelhantes em todo o território do bairro, com várias quadras sendo modificadas pelas construções de edifícios de 03 pavimentos onde antes haviam moradias térreas em lotes de $12 \times 30 \mathrm{~m}$. A partir do entendimento dessa lógica predominantemente mercadológica, em que o setor privado vem ditando as mudanças respaldadas por uma legislação obsoleta, é recomendado uma revisão nessa mesma legislação para combater esse modelo existente de edifícios multifamiliares isolados por muros, sem relação com espaços públicos e o monofuncionalismo das novas edificações da quadra (apenas o residencial). Com a utilização dos princípios da quadra híbrida (LIMA, 2017; FILHO, 2003; JACOBS, 2011; KARSSENBERG, 2015), a partir da inserção de edifícios de usos misto (comercial e habitacional) na escala do lote, como viabilidade possível e gradual, pode-se alcançar, em seguida, resultados satisfatórios de habitabilidade para a quadra como um todo, atendendo a diversos modos de viver e morar. 
Portanto, a proposta preliminar visa à conciliação da presença inevitável do mercado imobiliário com os instrumentos de gestão urbana capazes de conter o crescimento verticalizado danoso para os moradores, através de outra maneira de se construir na quadra. Assim, acredita-se que as quadras híbridas têm um poder catalisador para as mudanças positivas nos bairros se forem bem articuladas com a legislação urbanística de uso e ocupação do solo da cidade. Ressalva-se que cada bairro tem seu tecido urbano peculiar, e a distribuição das quadras híbridas depende das suas vocações socioespaciais devidamente compreendidas.

\section{CONCEITOS E CONTEXTUALIZAÇÃO}

\section{A Quadra}

Partimos do pressuposto que quadra é sinônimo de quarteirão. Segundo Lamas (2014), o quarteirão é conceituado como:

[...] um contínuo de edifícios agrupados entre si em anel, ou sistema fechado e separado dos demais; é o espaço delimitado pelo cruzamento de três ou mais vias e subdivisível em parcelas de cadastro (lotes) para a construção de edifícios. É também um modelo de distribuição de terra por proprietários fundiários. Como é também o modo de agrupar edifícios no espaço delimitado pelo cruzamento de traçados (LAMAS, 2014, p.88).

O autor considera o quarteirão um sistema antigo num processo geométrico elementar que ao longo do tempo foi adquirindo status de unidade morfológica na produção da cidade, e pode ser definida como "[...] a parte mínima identificável na estrutura urbana" (LAMAS, 2014, p.88).

Lamas (2014) aponta a relação entre as partes constituintes da quadra, os edifícios, os lotes, e as vias. A quadra, em muitos casos, é delimitada e circundada por três a quatro vias e ocupada por edifícios ou espaços públicos como praças. Os edifícios, por sua vez, podem se diferenciar em altura e em programa. Lamas entende que o quarteirão não independe dos elementos que compõem o espaço urbano, mas sim resulta do traçado das vias, do posicionamento dos edifícios, da forma dos lotes, dos espaços públicos, semipúblicos, privados, das regras geométricas de divisão fundiária do solo, do ordenamento e parcelamento do solo.

No Brasil, a Lei de Parcelamento do Solo (no 6766/1979) definiu a quadra como parte do parcelamento da gleba (unidade maior do solo), resultando internamente em lotes como menores parcelas do solo e visível divisão dos limites da propriedade privada dos espaços públicos.

\subsection{ASPECTOS LEGAIS E ESPACIALIDADES}

Toda e qualquer possível alteração no uso e ocupação do solo da cidade deverá estar prevista na legislação urbanística para o devido cumprimento pela população, caso contrário, as intenções para se construir no lote serão apenas compostas por ideias ou abstrações sem reflexo no amparo legal e na realidade do espaço construído. Na história moderna do país, a criação da lei de parcelamento do solo, Lei Federal no 6766 de 1979, foi um marco no planejamento e regulação urbanístico no Brasil, estabelecendo diretrizes de parcelamento, desmembramento de glebas em loteamentos, aberturas de vias e equipamentos urbanos, moldando a forma urbana das cidades, conforme a aplicabilidade das leis de uso e ocupação do solo de cada cidade, complementado com o macro-zoneamento do Plano Diretor municipal.

Surge daí, há mais de 39 anos, a maneira de ocupar os lotes nas cidades, valorizando a escala privativa do lote, e deixando em segundo plano os espaços públicos, sobretudo a relação com as calçadas. Foi dada demasiada importância ao zoneamento das cidades em termos de disciplinamento das suas funções (uso residencial, comercial, institucional, lazer, circulação), aos indicadores urbanísticos no lote (taxa de ocupação, índice de aproveitamento, recuos, solo permeável), gabarito, ao edifício em si, mas foram deixadas de lado, prioritariamente, as relações das pessoas e a escala humana nos bairros. Reforçado pela cultura do automóvel, muitas cidades foram desenhadas para abrigar os veículos automotores, construindo autoestradas, viadutos, alargando vias, gerando estacionamentos, e deixando cada vez mais espaços para carros e menos espaços públicos para as pessoas (calçadas, praças, parques). 
Por décadas, a dimensão humana tem sido um tópico do planejamento urbano esquecido e tratado a esmo, enquanto várias outras questões ganham mais força, como acomodação do vertiginoso aumento do tráfego de automóveis. Além disso, as ideologias dominantes de planejamento - em especial, o modernismo - deram baixa prioridade ao espaço público, às áreas de pedestres e ao papel do espaço urbano como local de encontro dos moradores da cidade (GEHL, 2013, p.3).

Desta forma, para que as ideias das quadras híbridas sejam implementadas nos bairros, é recomendável que sejam previstas na legislação urbanística, sobretudo na lei de uso e ocupação do solo, no mapa de Zoneamento da cidade. Tal mudança deve ocorrer também na tabela de parâmetros urbanísticos conformes as figuras apresentadas a seguir (figuras 4 e 5).

Figuras 4 e 5: Tabela de usos e indicadores urbanísticos e mapa de João Pessoa, situação atual (esquerda) e situação proposta. É proposta a criação de uma nova Zona no mapa de uso e ocupação do solo (ZR4). A tipologia RH (6) refere-se ao edifício híbrido proposto, com uso comercial e/ou serviços no térreo e flexibilidade de vagas (considerar $70 \%$ das vagas para automóveis), podendo ser reduzida pela metade no recuo frontal conforme disponibilidade de transportes públicos e ofertas de quadras híbridas nos bairros.

\begin{tabular}{|c|c|c|c|c|c|c|c|}
\hline \multicolumn{8}{|c|}{ ZONA RESIDENCIAL 3 (ZR3) } \\
\hline USOS & \multicolumn{2}{|c|}{ LOTE[] } & \multirow{2}{*}{\multicolumn{5}{|c|}{\begin{tabular}{l|l|l|} 
& EDIFICACAO $(A)$ \\
AFASTAMENTOS
\end{tabular}}} \\
\hline \multirow[b]{2}{*}{ merumidos } & \multirow{2}{*}{$\begin{array}{l}\text { Mera } \\
\text { newive }\end{array}$} & \multirow{2}{*}{ 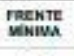 } & & & & & \\
\hline & & & $\begin{array}{l}\text { ocumc. } \\
\text { wanis. }\end{array}$ & 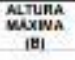 & \multicolumn{2}{|c|}{\begin{tabular}{l|l} 
FHEVIE & LATERAL \\
\end{tabular}} & FuMbos \\
\hline F1 & 360,00 & 12.00 & sa & & 6.00 & 1.50 & 3.02 \\
\hline $\mathrm{F}_{2}(1)$ & 450,00 & 15.00 & 60 & $2 P V$ & 6.00 & 9.60 & 3.00 \\
\hline R3 & - & - & 50 & $2 \mathrm{PV}$ & 6.00 & 1.50 & 3.02 \\
\hline R4 & \multicolumn{7}{|c|}{ CONDOEANIO HOAIZONTAL VER ANEXOO OS } \\
\hline Fis $(2)$ & 600,00 & 15.00 & 40 & PAt & 6.00 & 4.00 & 4.02 \\
\hline RS & 600,00 & 1500 & 35 & $\triangle P Q$ & 5.00 & 3.00 & 3.00 \\
\hline RK & $900,0 \mathrm{~A}$ & nos & 90 & - & $s a n$ & 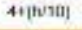 & $4 \cdot(0 \div 11)$ \\
\hline मा8 & 30000 & 12.00 & 55 & $\begin{array}{l}\text { in apv } \\
\text { oujpV }\end{array}$ & 5,00 & 1.50 & 300 \\
\hline$a=5 L(3)$ & 360,00 & 12.00 & 60 & $3 \mathrm{PV}$ & 6.00 & 1.50 & 3.00 \\
\hline$C \mathrm{C}-3 \mathrm{~B}$ & 450,00 & 15.00 & 50 & $3 P V$ & 6.00 & 2.00 & 3.00 \\
\hline L & $\theta 00, \infty$ & 15.00 & 50 & $2 \rho v$ & 5.00 & 1.50 & 300 \\
\hline PP (4) & 360,00 & 12.00 & 60 & $2 \mathrm{PV}$ & 6.00 & 1.50 & 3.00 \\
\hline
\end{tabular}

\begin{tabular}{|c|c|c|c|c|c|c|c|}
\hline \multicolumn{8}{|c|}{ ZONA RESIDENCIAL 3 (ZR3) } \\
\hline \multirow{2}{*}{\begin{tabular}{|c|} 
USOS \\
कERUETInDS
\end{tabular}} & \multicolumn{2}{|c|}{ LOTEC) } & \multicolumn{5}{|c|}{$\begin{array}{l}\text { EDIFICACAAO }|A| \\
\text { NASTAVENTOE }\end{array}$} \\
\hline & $\begin{array}{l}\text { sasa } \\
\text { whame }\end{array}$ & $\begin{array}{l}\text { FRENTE } \\
\text { whius }\end{array}$ & $\begin{array}{l}\text { ocupac } \\
\text { whandat }\end{array}$ & 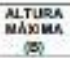 & \multicolumn{2}{|c|}{$\begin{array}{l}\text { NASTAUEK } \\
\text { FEENTE LATERAL }\end{array}$} & Pungas \\
\hline 91 & 30500 & 1200 & 50 & . & 500 & 2.50 & 300 \\
\hline R2 (1) & 452,00 & 1500 & 50 & $2 \mathrm{FV}$ & 500 & 1.50 & 3.00 \\
\hline 9.3 & - & - & 5) & $2 \mathrm{PV}$ & 500 & . sn & 300 \\
\hline RA & \multicolumn{7}{|c|}{ CONDOMIHIO HORZONIRL VER AREXOOS } \\
\hline les $(2)$ & 80000 & 9500 & 40 & $4 L^{4+}$ & 500 & $4(0)$ & 400 \\
\hline F5 & 608,00 & 1500 & 36 & $4 F V$ & 500 & 3.50 & 3.00 \\
\hline R6 & $902, \infty 0$ & 20.00 & 30 & - & 500 & $4+\left|h^{4} 10\right|$ & $4+($ liv10) \\
\hline fet;s] & 720,00 & 2405 & ss & $4 \mathrm{FV}$ & $5 \mathrm{~m}$ & $\sin 0$ & 252 \\
\hline$\alpha=5453$ & 360,00 & 1200 & 50 & 3PV & 500 & 1.80 & 300 \\
\hline$C B=9 B$ & 450,00 & 15.00 & bo & $3 \mathrm{FV}$ & 500 & 2.00 & 3.00 \\
\hline II & 600,00 & 15.00 & 50 & $2 \mathrm{PV}$ & 500 & 1.50 & 3.05 \\
\hline [PP : 14] & 300,00 & 1200 & 50 & $2 \mathrm{FV}$ & 500 & 1.50 & 3.00 \\
\hline
\end{tabular}

Fonte: SEPLAN, editado pelo Urbanicidade.

Figura 6: Trecho do Mapa Zoneamento- Código de Urbanismo. O Bancários encontra-se na Zona Residencial -ZR3. É proposto que seja criado uma nova Zona Residencial, a ZR4, na qual prevê a quadra híbrida nos bairros.

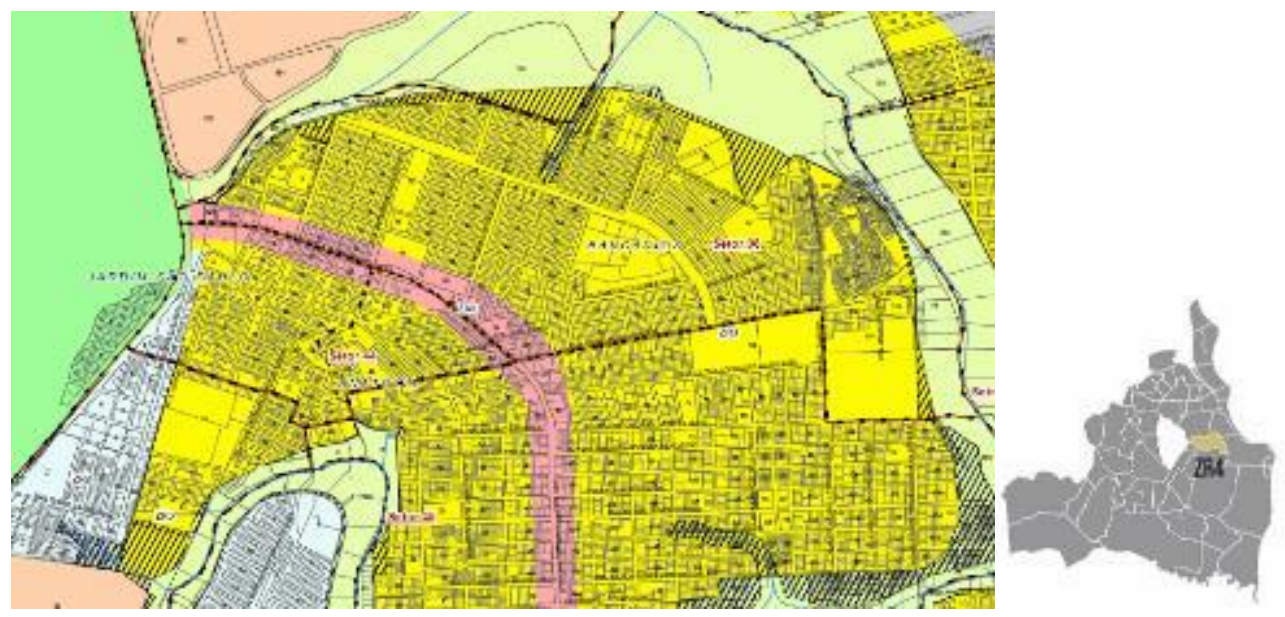

Fonte: SEPLAN, editado pelo Urbanicidade.

\subsection{AS ESCALAS URBANAS}

Uma das críticas direcionadas ao planejamento urbano tecnocrático diz respeito ao olhar visto de cima, sem considerar a vida ao nível dos olhos na cidade e a escala humana. Com isso, elaboram-se mapas, planos e zoneamento sem conhecer a dinâmica cotidiana dos bairros, suas interações e vivências das pessoas no dia a dia. Rompendo com esse olhar, a proposta aqui abordada parte de uma compreensão de que a escala humana é prioridade, ou conforme GEHL (2013), vida, espaço, edifícios devem vir nessa nessa ordem.

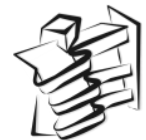


Observa-se, portanto, que as mudanças podem partir de uma adequada compreensão entre as escalas urbanas, iniciando por uma hierarquia que compreenda a escala da rua, da quadra, do bairro sistematicamente, contrapondo-se ao zoneamento ortodoxo que parte da escala macro, distante da vida no chão, e define indicadores urbanísticos herméticos que regulam os afastamentos, a taxa de ocupação, os gabaritos e os usos dos edifícios, sem avaliar os impactos nos espaços públicos e na vida dos moradores.

Figura 7 Mapa Divisão das Zonas - Área Urbana. Plano Diretor de João Pessoa. O Bancários encontra-se na Zona Adensável não Prioritária.

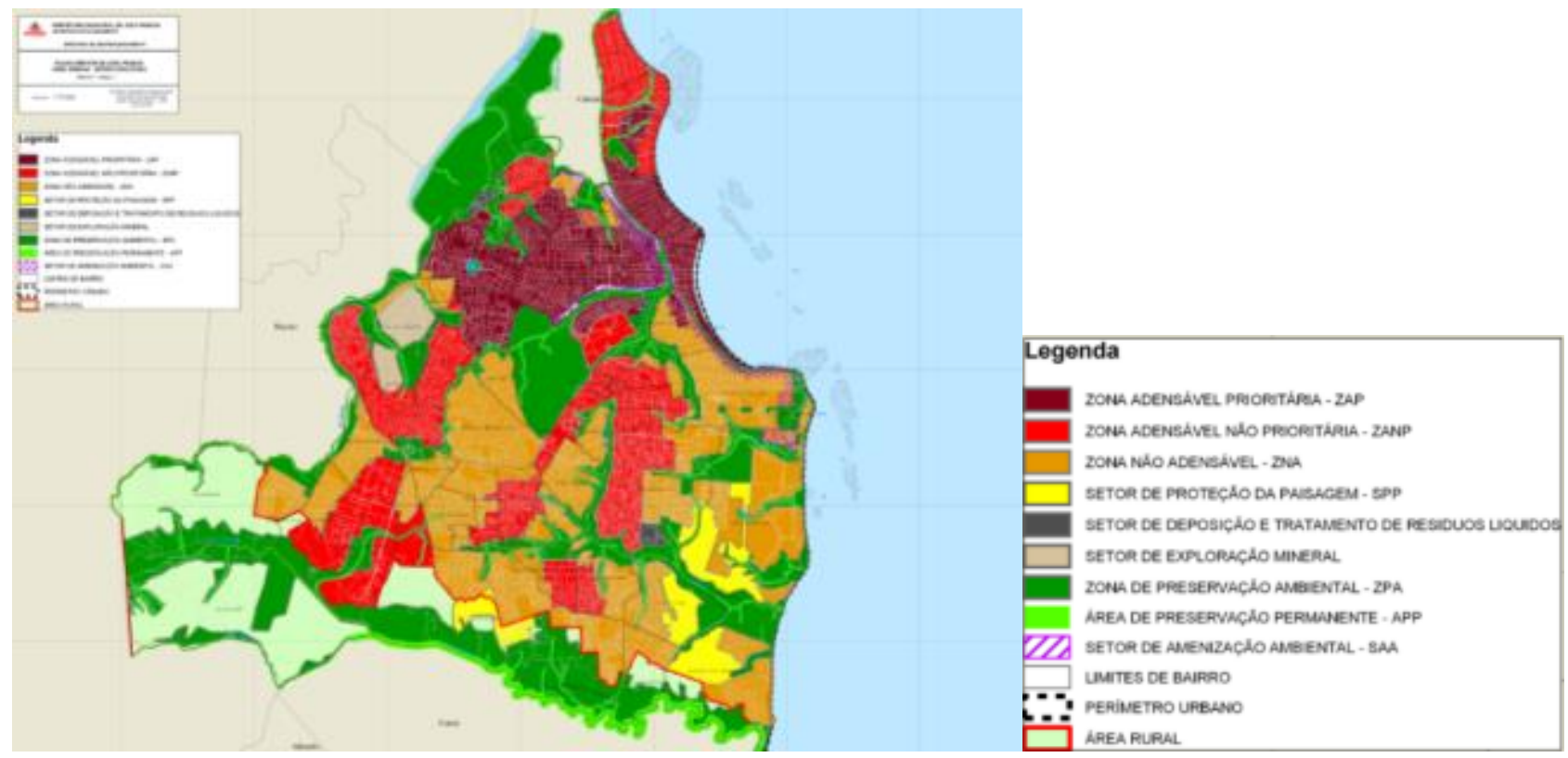

Fonte: SEPLAN.

Ao invés de serem estudados os espaços públicos que se desejam e, daí, serem definidos os volumes dos edifícios, constroem-se os edifícios conforme o interesse imobiliário dos terrenos. Isto significa que, quando nos abstemos de projetar para o espaço urbano em benefício de índices, estamos transferindo para o lote, para a propriedade privada, a definição da forma urbana, a definição do espaço público. Mas, paradoxalmente, é a definição dos volumes e dos espaços públicos, na busca pela melhor cidade, o que legitima o Estado na função de legislar urbanisticamente, de determinar o que se pode construir, onde e em que condições. (MAGALHÃES, 2015, p.35).

\section{DENSIDADE URBANA E TENDÊNCIAS NA QUADRA OBJETO DE ESTUDO}

Densidade urbana é a relação entre o número de residentes de um determinado lugar e a área onde eles vivem. Como resultado, é possível informar o grau de concentração da população, variando conforme a intensidade de uso e ocupação do solo (ACIOLY, 1998). É dividida em densidade bruta e líquida, a primeira relaciona a população residente e a área bruta na qual ela reside, incluindo ruas, espaços públicos. Já a densidade líquida, só considera relação da população residente com a área líquida residencial específica. É um conceito que está diretamente relacionado ao planejamento urbano, podendo ser específico para cada bairro, conforme uso e ocupação do solo, tecido urbano, sistema viário, capacidade de suporte da infraestrutura, drenagem urbana, oferta de transporte coletivo, modos de vida de uma população, tipologias habitacionais e aspectos culturais.

No caso em questão, para avaliar a densidade urbana na quadra ao longo dos anos, foram definidos três momentos de ocupação e transformação urbana a partir da verticalização (Figura 8). A gênese (1980) quando foram entregues as moradias do bairro, a situação atual (2018) com alguns edifícios verticalizados e a tendência futura hipotética, em 2025. No primeiro momento, observa-se uma baixa densidade - 98 hab/ha devido à tipologia de casas térreas e unifamiliares. Em 2018, a densidade já sofreu um aumento considerável com a construção de prédios multifamiliares de 03 pavimentos, ou seja, em mais de três décadas, a densidade aumentou mais de $250 \%$, o que já é verificado na paisagem urbana local. No cenário futuro em 2025 (e não tão distante) estima-se que a densidade habitacional alcance 497 hab/ha, valor considerado alto pelo perfil 
do bairro, com possível saturação da infraestrutura - sistema viário, rede coletora de esgoto, energia elétrica, limpeza urbana, custo de manutenção.

Nas figuras 9 e 10, são apresentados conceitos e implicações da densidade urbana, sabendo que nem sempre se pode distribuir a massa construída a partir de uma gleba de um hectare desocupada, por exemplo. Uma das realidades mais vistas nas cidades são as modificações por lotes remembrados ou por lote, evidenciando a forma pontual de intervenção com reflexos no entorno. Por isso, a preocupação de adotar maneiras de aferir tais mudanças na quadra, fenômeno urbano bastante comum.

Figura 8: Evolução urbana da densidade habitacional - saturação da infraestrutura no futuro próximo.
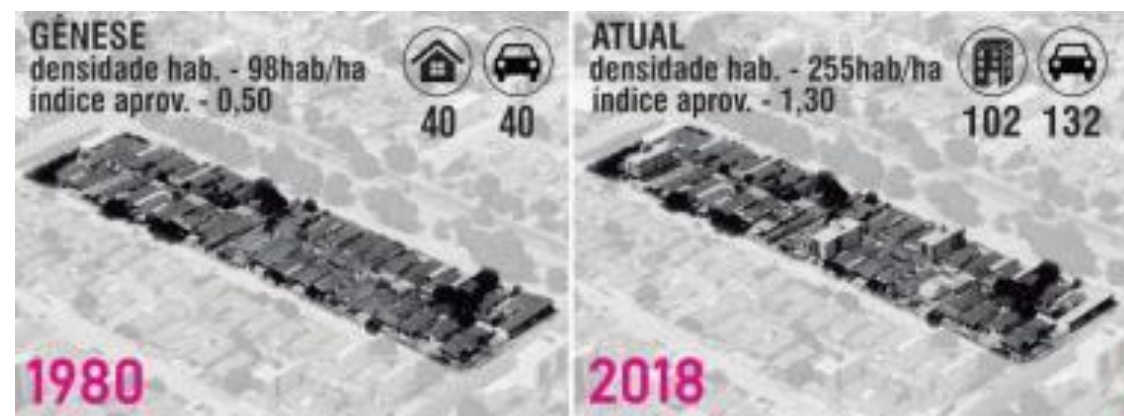

TENDENNCIA densidade hab. - 497hab/ha (9.) indice aprov, $-1,60$

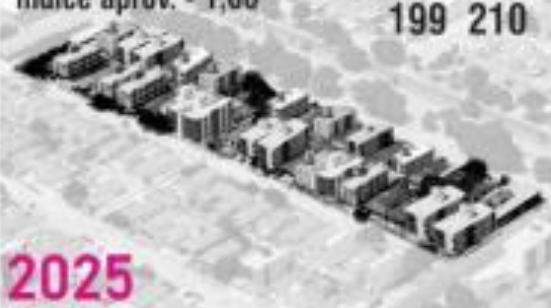

Fonte: Urbanicidade.

Figura 9: Vantagens e problemas da alta e baixa densidade urbana.

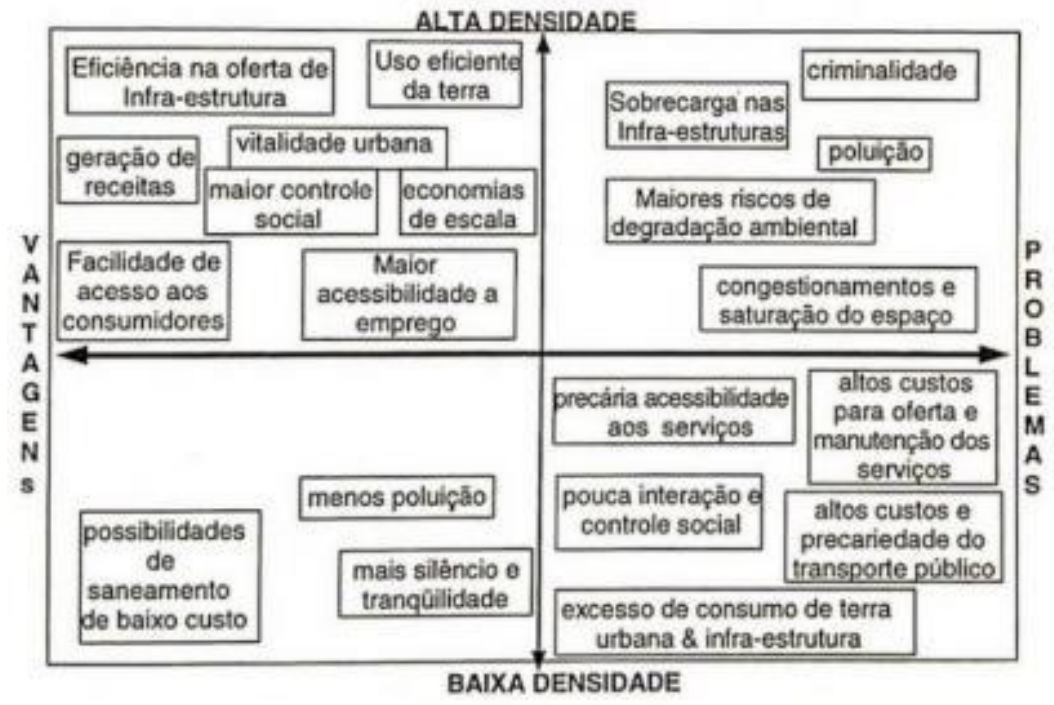

Fonte: Acioly e Davdson (1998).

Para cada caso específico se deve estudar a densidade econômica ou ótima, levando-se em conta o nível e o gênero de vida da população, a estrutura ecológica da cidade e, sobretudo, o custo unitário dos equipamentos urbanos. Deve-se, dentro da realidade local, adensar ao máximo a população urbana. No Brasil, parece que a densidade econômica se situa entre 250 e 450 habitantes por hectare - densidade residencial bruta média (FERRARI, 1979, p.350). 
Figura 10: Comparativo de densidades urbanas líquidas numa área de 1 ha em distintas formas edificadas numa área urbanizada. No caso "A", "B" e "C", formas distintas com a mesma densidade. No caso "D", foram acrescidos dois pavimentos ao modelo "B", para recalcular.
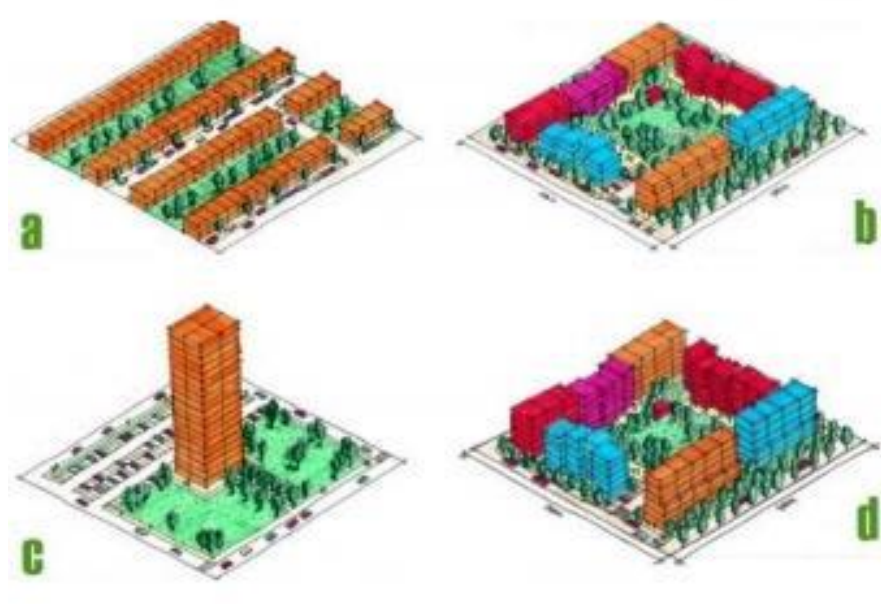

a Densidade bruta $-260 \mathrm{hab} / \mathrm{ha}$

b Dersidade hruta $=260 \mathrm{hab} / \mathrm{hil}$

C Dersidade bruta $=260$ hab $/$ ha Custo urbanizaça aprox. = US\$ $270 \mathrm{mil} / \mathrm{ha}$

d Dersictade truta $=510 \mathrm{hmb} / \mathrm{hat}$ Custo urbanizaçå a prox. - US\$ $310 \mathrm{mil} / \mathrm{h}$ a

Custa de urbanização 75 hab/has = U5\$ 250.000 (US\$ 3.334 per capita)

Custo de urbanizaça 500 habjha - US\$ 320.000 (USS 5.33 per enpita!)

Fonte: Silva, G. J. A. (2016).

A implementação da densidade urbana conforme particularidades espaciais de cada bairro favorece a distribuição equilibrada de serviços urbanos de qualidade a maior parte da população, reduzindo a necessidade de deslocamentos motorizados, e incentivando a movimentação de pedestres nos espaços públicos. Neste sentido, tal reflexão alinha-se também ao conceito de cidade compacta de Richard Rogers (1997), um dos estudiosos sobre os usos polifuncionais e o surgimento de novas centralidades nas cidades (Figura 11).

Figura 11 - Esquema comparativo entre o zoneamento de usos distantes entre si que induz a utilização do automóvel e o núcleo urbano compacto com uso misto que resulta em vitalidade e sustentabilidade, permitindo o deslocamento a pé ou de bicicleta.

\section{Os núcleos compactos e de uso misto reduzem as necessidades de deslocamentos e criam bairros sustentáveis e cheios de vitalidade}

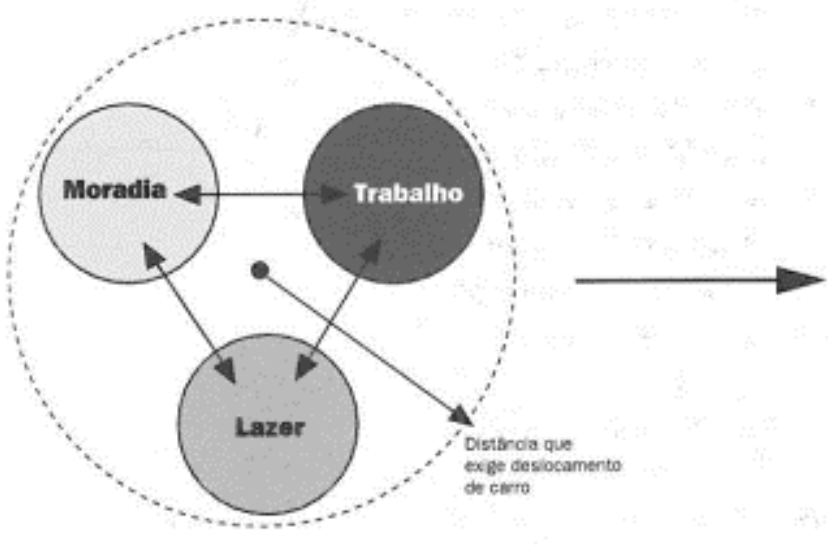

O zoneamento das atividades induz à utilização e dependência do automóvel particular.

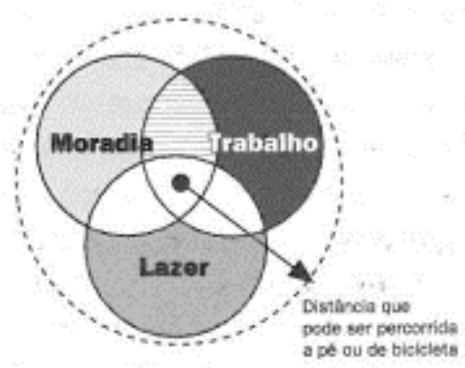

Núcleos compactos reduzem as distâncias e permitem o deslocamento a pé ou de bicicleta.

Fonte: Rogers (1997, p.39)

\section{A SITUAÇÃO ATUAL}

O bairro dos Bancários foi fundado em 1980 com financiamento do Banco Nacional da Habitação (BNH), possui uma população de 11.863 habitantes (Censo IBGE 2010), e estima-se que atualmente tem mais de 14.000 moradores. Nos últimos 10 anos vêm sendo transformado pela verticalização sem planejamento e pelo uso habitacional multifamiliar restrito, com evidentes sintomas no espaço urbano. As casas térreas estão 
sendo demolidas e substituídas por prédios de dois pavimentos nos lotes $12 \times 30 \mathrm{~m}$. No entanto, essas mudanças não contribuem para a qualidade de vida coletiva no bairro, pois prioriza a escala privada e os investidores do capital imobiliário que lucram com os altos preços dos imóveis sem regulação do poder público. Com uso apenas habitacional na maioria das quadras, as demandas cotidianas dos moradores em termos de provisão de comércios e serviços não são atendidas. Desta forma, é preciso depender do automóvel ou caminhar longas distâncias para fazer compras e acessos aos serviços básicos na principal Avenida do Bairro, a Emp. João Rodrigues Alves.

Na quadra objeto de estudo, limitada pelas seguintes vias: Rua Waldemar Mesquita Acyoli ao norte, Rua Bancário Antônio Jacinto de Souza ao leste, Rua Wagner Alexandrino B. Japyassu ao sul, nos Bancários, observa-se a tendência da verticalização que vem mudando a paisagem e a dinâmica urbana no bairro. Esse fenômeno ocorre em várias quadras, o que demonstra a necessidade da reflexão para tentar alternativas que amenizem alguns impactos nocivos para a população. É, portanto, um estudo piloto local que reflete o problema global do bairro. Os principais motivos pela escolha desta quadra foram: localização próxima a um equipamento comunitário relevante que é a Escola Municipal Aruanda, gradual presença de comércios, embora de forma aleatória (restaurantes, pizzarias), já apontando a carência de comércio observado pelos próprios moradores e o limite com a Rua Waldemar Mesquita Acyoli, conhecida como as "três ruas", importante marco referencial do bairro.

\subsection{IMPACTOS GERADOS}

\section{Muro, segregação e proximidade entre os prédios}

Os lotes continuam sendo fechados por muros, com reflexo na desertificação das calçadas e ausência de comércios no térreo para o atendimento das necessidades cotidianas dos moradores.

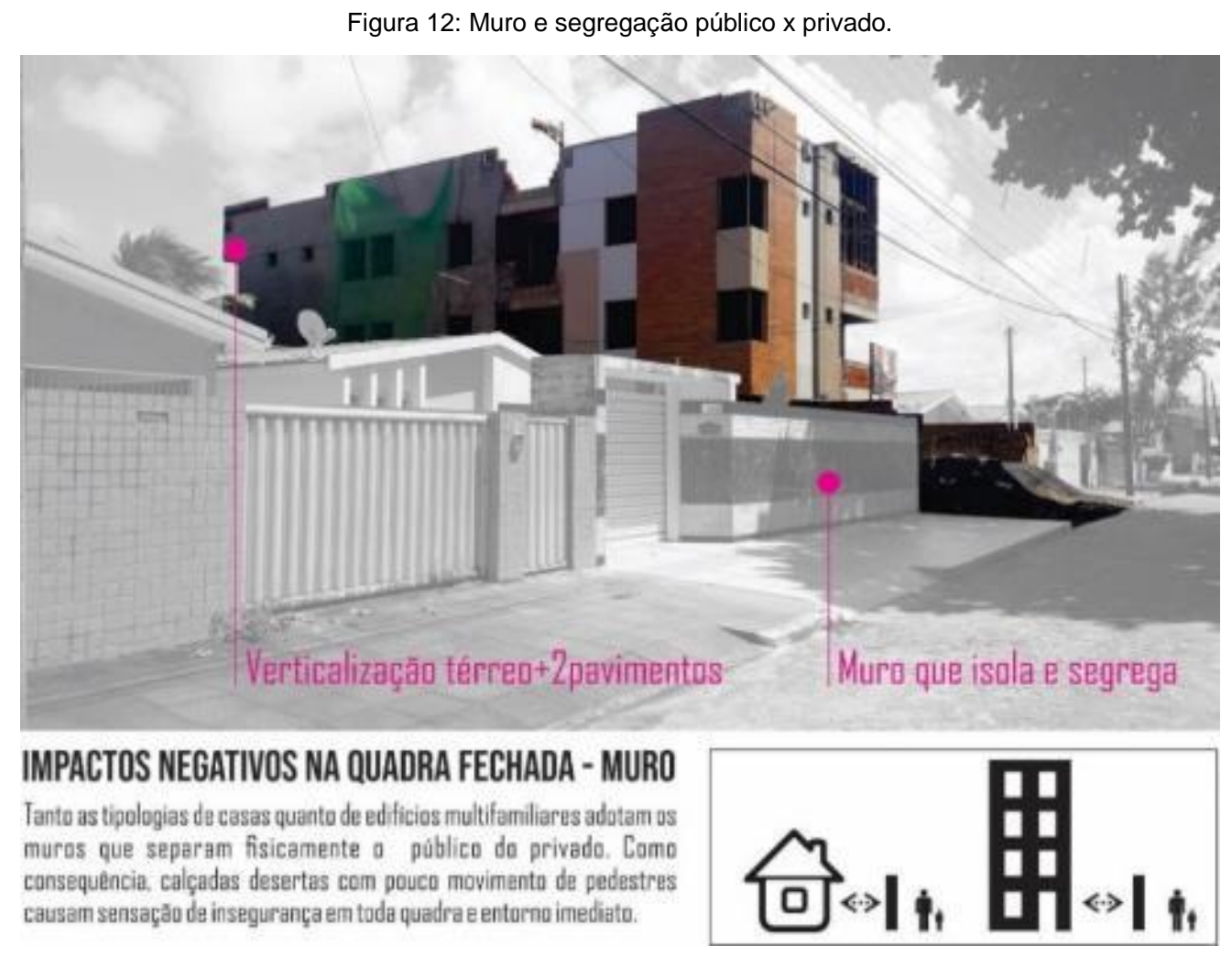

Fonte: Urbanicidade.

Os afastamentos laterais dos edifícios de três pavimentos (10m altura) são construídos a $1.50 \mathrm{~m}$ do limite do lote de $12 \times 30$. Entre eles, a distância é de apenas $3,00 \mathrm{~m}$, o que compromete a incidência dos ventos predominantes e a privacidade dos apartamentos. Ainda assim, os imóveis são vendidos com valores altíssimos, cerca de $\mathrm{R} \$ 3501,00 / \mathrm{m}^{2}$. 
Figura 13: Uso R8 (térreo+pav.) predominante na quadra, são construídos muito próximos entre eles.

Pela proximidade entre os prédios, 3.00m apenas, sacrifica-se o conforto ambiental e a privacidede das maradares que pagam mais de RS 180.000 por um apartamenta de dais

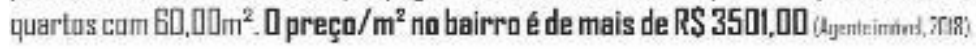
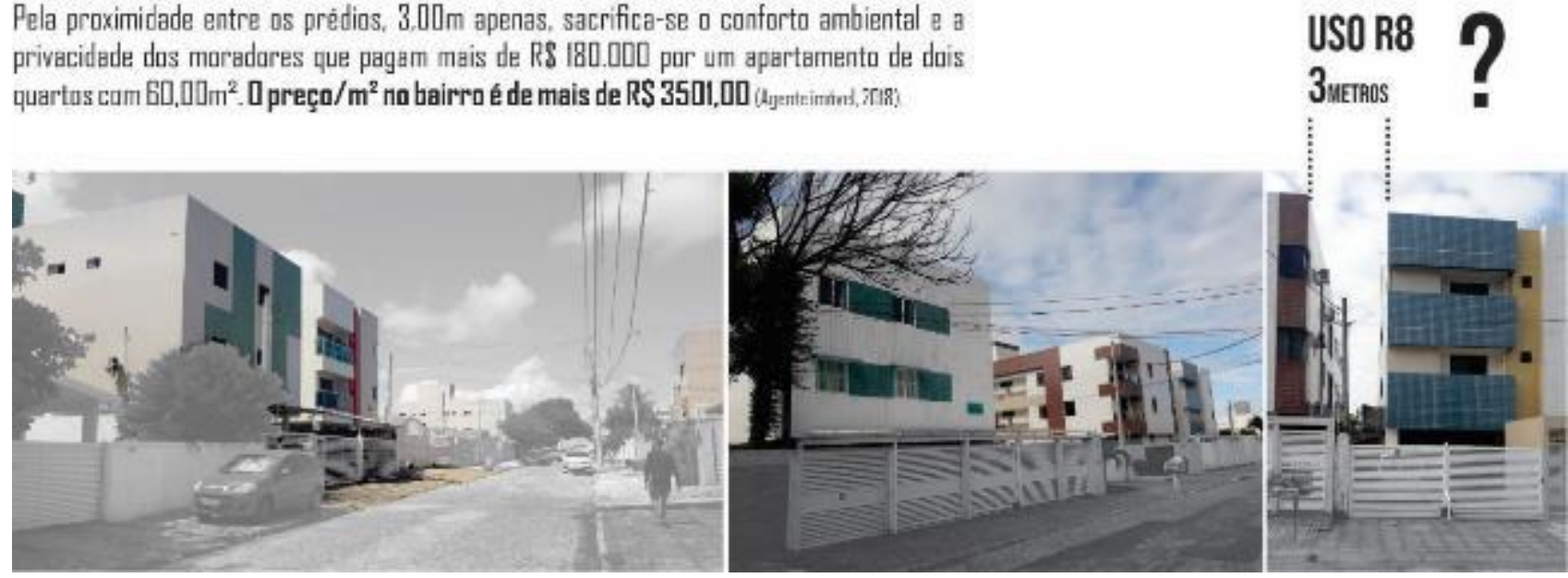

Fonte: Urbanicidade.

\section{Aumento da frota de veículos}

Um dos impactos mais danosos nessa lógica da verticalização e adensamento sem planejamento é o aumento vertiginoso da frota de automóveis particulares. Segundo Henriques (2013), só em 2013 houve um aumento de 750 veículos em circulação no bairro. Estima-se que em 2025 a quadra estudada abrigará mais de 200 veículos ou a proporção de cinco carros por lote de 12×30m, no início nos anos 1980, tinham-se apenas quarenta. Considerando como um fato que pode se replicar no bairro, as consequências são preocupantes, pois afetam a todos indistintamente. Poluição, congestionamento, acidentes no trânsito, custos, comprometimento das relações de vizinhança são alguns dos problemas dessa externalidade negativa.

Figura 14: Gráfico revela o crescimento exponencial da frota de veículos na quadra, provocado pelo adensamento e relação de uma vaga para cada apartamento exigida pelo Código de Urbanismo da prefeitura. Estima-se que em 2025 terão mais de 200 veículos na quadra estudada.

\section{RESIDÊNCIAS X CARROS}

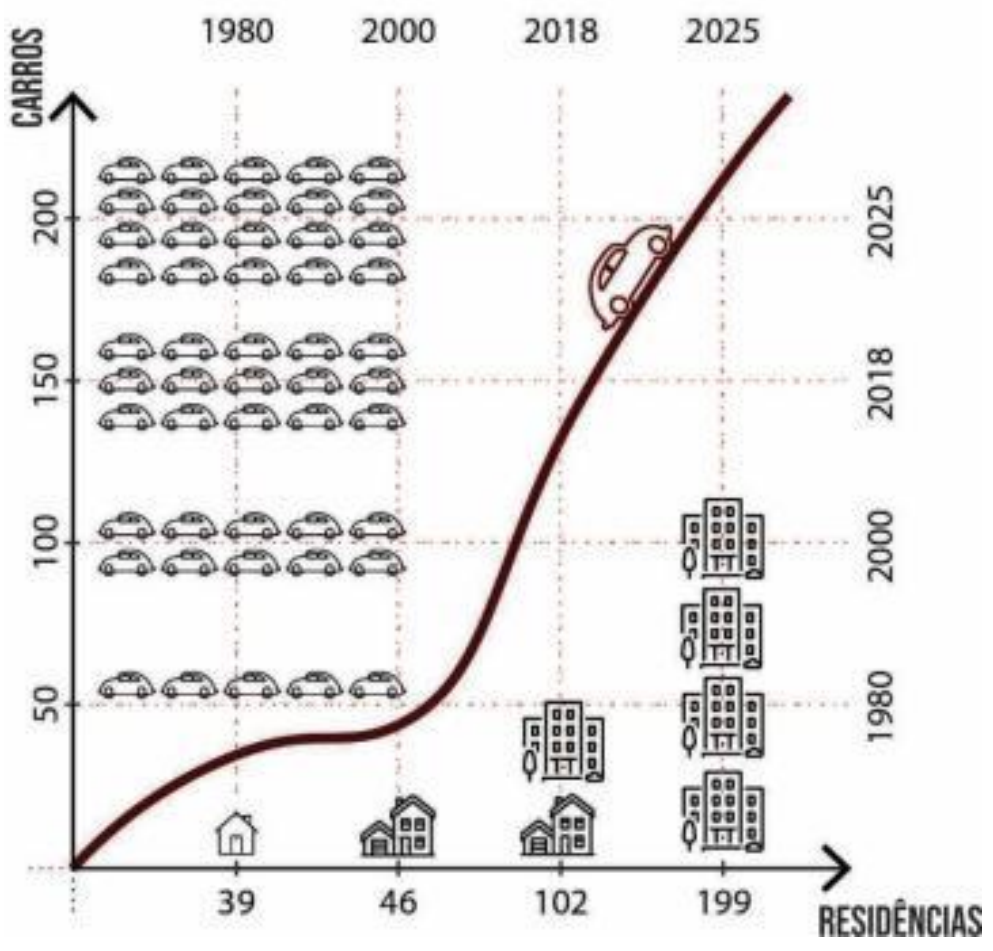

Fonte: Urbanicidade. 


\section{A PROPOSTA}

\section{Conceitos e o remembramento proposto}

As transformações na quadra podem ocorrer, ao longo dos anos, conforme a dinâmica do mercado imobiliário, com a viabilidade econômica e com a qualidade de vida urbana coletiva. Tal medida pode ser alcançada pelo estímulo à caminhada, através da oferta de uso misto na quadra (comércio, serviço, moradia, espaços públicos qualificados), acessados a pequenas distâncias (máximo de $500 \mathrm{~m}$ ). Tipologias variadas podem ser concebidas, desde que se mantenha o princípio de multifuncionalidade e pedestrianismo. Neste sentido, o pavimento térreo com comércios (farmácia, mercadinho, lanchonetes, bares, salão de beleza, lojas, etc.) equilibradamente espalhados nas quadras, é fundamental para a animação urbana e interações sociais. É proposto que se inicie pelo remembramento de dois lotes em quadras estratégicas em termos de localização e catalisação dos efeitos positivos no entorno. O poder público poderá assumir a responsabilidade de gestão do território no bairro, aplicando mudanças ordenadoras na legislação urbanística (item abordado mais adiante).

Verifica-se que na situação atual dos lotes de $12 \times 30 \mathrm{~m}$, a predominância é pela demolição de casas que são substituídas por prédios de 03 pavimentos, e 08 apartamentos de 02 e 03 quartos, além de 08 vagas para carros. É proposto o remembramento de dois lotes $(24 \times 30 \mathrm{~m})$, implantando edifício híbrido (uso misto) com uso comercial no térreo e portão recuado que separa o público do privado. Desta forma se incentiva a adoção de fachadas ativas, o uso misto na quadra e a indução de mais movimento de pessoas nas calçadas proporcionando maior sensação de segurança. As distâncias entre os edifícios são maiores, favoráveis para melhor porosidade dos ventos. Tal intenção visa se adequar ao perfil do mercado imobiliário de forma a viabilizar a mudança sem grandes dificuldades em termos cartoriais e da propriedade privada, mas sem deixar de contemplar a urbanidade. Foram previstas 13 vagas para carros, 05 a menos em relação a situação atual que seria 16 vagas para cada dois lotes, mais 10 vagas para bicicletas (paraciclos), podendo ser reduzidas as vagas conforme eficiência do sistema de transporte público e integração entre os modais não poluentes.

Figuras 15 e 16: Proposta do remembramento gradual de dois lotes de $12 \times 30$ e diretrizes.

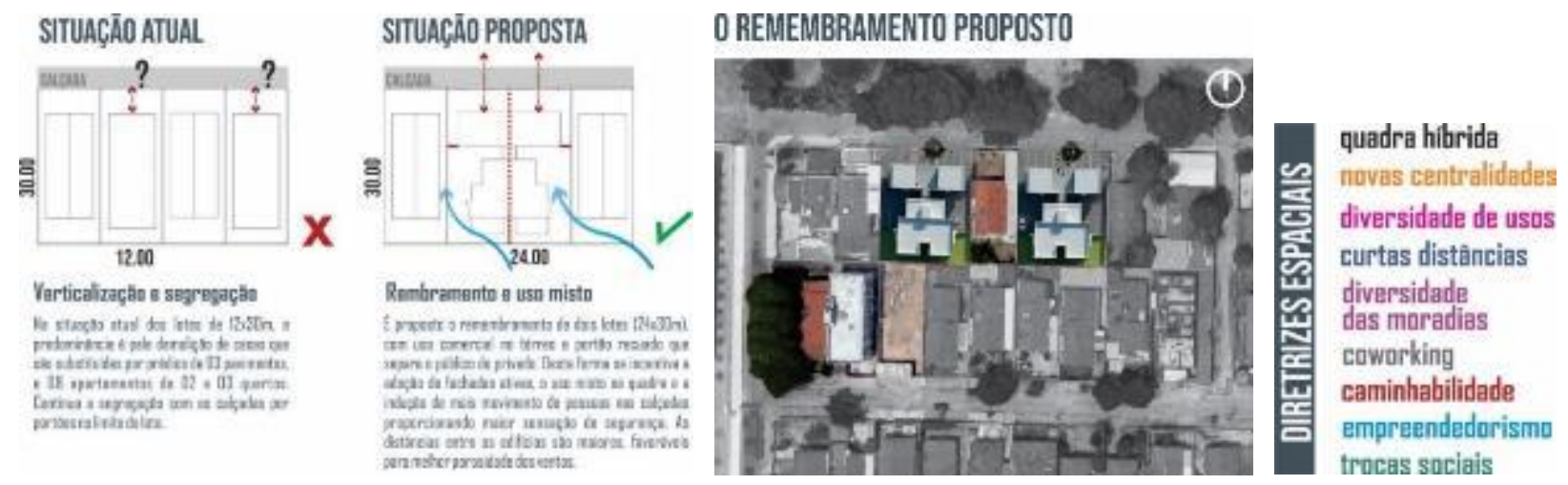

Fonte: Urbanicidade.

\section{Quadras híbridas no bairro e caminhabilidade}

Garanta uma caminhabilidade adequada e muito do restante virá a seguir (SPECK, Jeff, 2016, p.28).

Para combinar quadra híbrida com caminhabilidade, foram investigados alguns conceitos básicos, entre eles os de GEHL (2013), SPECK, (2016), JACOBS (2011). Eles consideram que quadras curtas, com atrativos para a caminhada e animação urbana, perpassam pela mistura de usos e diversidade social. Mas a qualidade do percurso, o estado de conservação das calçadas, o clima, a sensação de segurança e a vigilância social também interferem na indução da caminhada. 
A distância aceitável de caminhada é um conceito relativamente fluido. Algumas pessoas andam felizes por muitos quilômetros, enquanto para alguns idosos, deficientes ou crianças, mesmo curtas caminhadas são difíceis. A maioria das pessoas está disposta a percorrer cerca de 500 metros. A distância aceitável, porém, também depende da qualidade do percurso (GEHL, 2013, p.121).

Um tema bastante preocupante na atualidade é a insegurança nos bairros. Neste sentido, desde os anos 1960, JACOBS (2011) alertava que:

\begin{abstract}
O requisito básico da vigilância é um número substancial de estabelecimentos e outros locais públicos dispostos ao longo das calçadas dos distritos; deve haver entre eles sobretudo estabelecimentos e espaços públicos que sejam utilizados a noite. Lojas, bares e restaurantes, os exemplos principais, atuam de forma bem variada e complexa para aumentar a segurança nas calçadas (JACOBS, 2011, p.37).
\end{abstract}

Significa que quanto mais variações de comércios na quadra, que funcionem de manhã, de tarde e à noite, acessíveis a curtas distâncias, mais se terá movimento de pessoas e vigilância social nas calçadas, proporcionadas pelos "olhos da rua". No caso do bairro dos Bancários, isto pode ser proporcionado alterando a forma urbana de algumas quadras. É possível, neste sentido, definir quadras específicas que possam atuar enquanto efeito multiplicador das mudanças conforme os conceitos abordados da quadra híbrida (diversidade de usos, caminhabilidade, trocas sociais). Acredita-se que pelo menos cinco quadras podem cumprir esse papel, atuando nas transformações benéficas para a população (ver figura 19). A escolha dessas quadras decorreu dos seguintes critérios: (1) localização distante dos eixos viários principais que já concentram oferta de comércios e serviços; (2) áreas com concentração de moradias térreas, mas em processo de verticalização visadas pelo mercado imobiliário; (3) potencial de influência no entorno de até 500 metros de distância a partir da quadra de intervenção.

Figura 17: Área de influência no entorno da quadra híbrida objeto de estudo. Cerca de 400 famílias podem ser beneficiadas por cada quadra híbrida implantada no bairro.

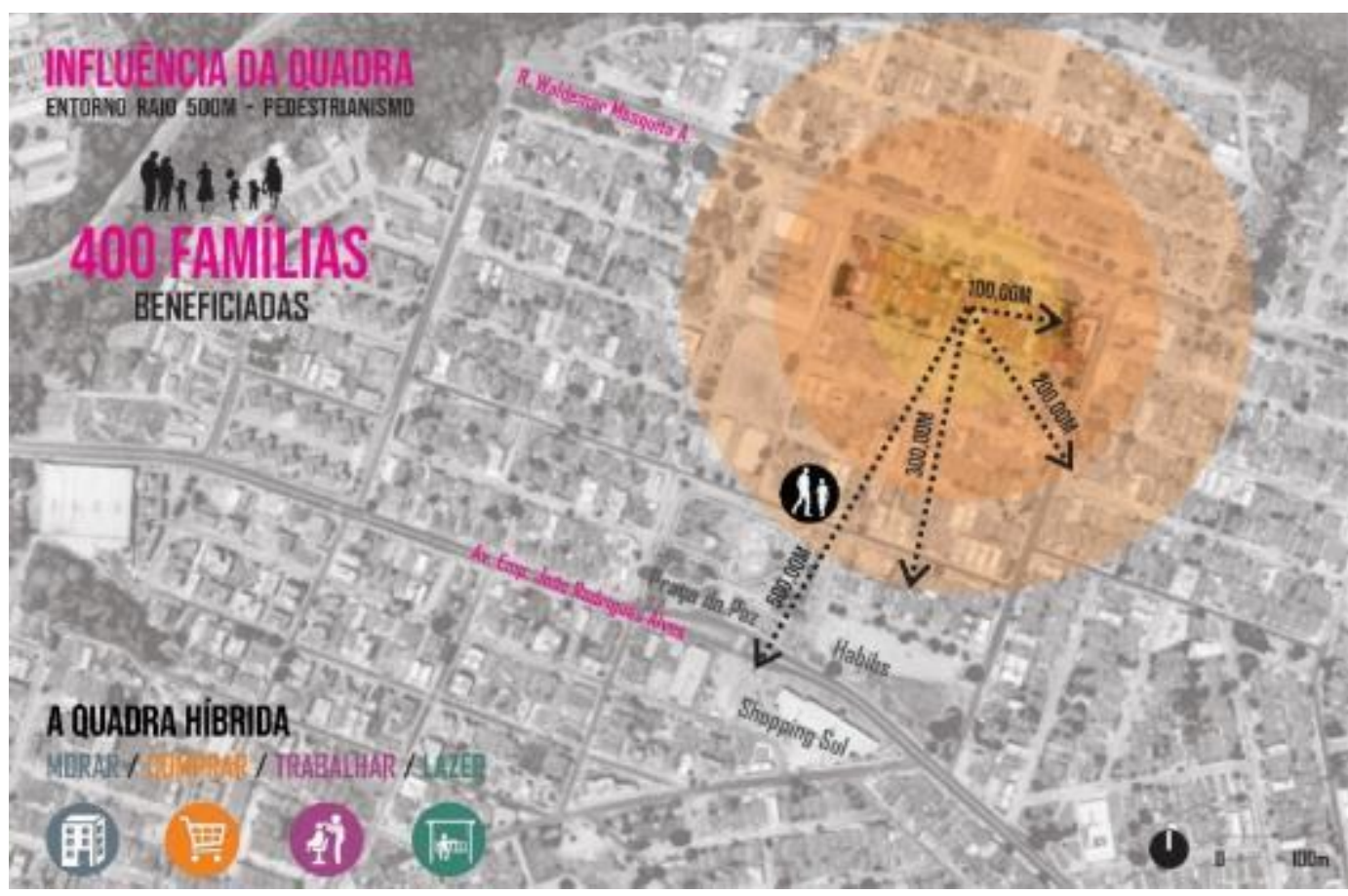

Fonte: Urbanicidade. 
Os pedestres e as famílias das quadras vizinhas poderão ser beneficiados pela quadra híbrida e seus comércios e serviços previstos devido as curtas distâncias para serem percorridas a pé (até $500 \mathrm{~m}$ ). Esta característica espacial pode incentivar a caminhada, desestimular o uso do automóvel particular, incrementar a economia local e gerar maior movimento de pessoas nas calçadas.

$\mathrm{Na}$ implantação da quadra híbrida em um cenário de transformação até 2025, se investigam outras formas de ocupação de edifícios na condição de remembramento de mais de dois lotes e ruptura do paradigma danoso da cultura do automóvel, oferendo espaços semi-públicos pelos pátios gerados e mais fachadas capazes de gerar maior vitalidade urbana.

Figura 18: Quadra híbrida, cenário de transformação em 2025 com uso misto (habitacional, comercial e entretenimento) distribuídos de forma dinâmica e equilibrada com o uso habitacional.

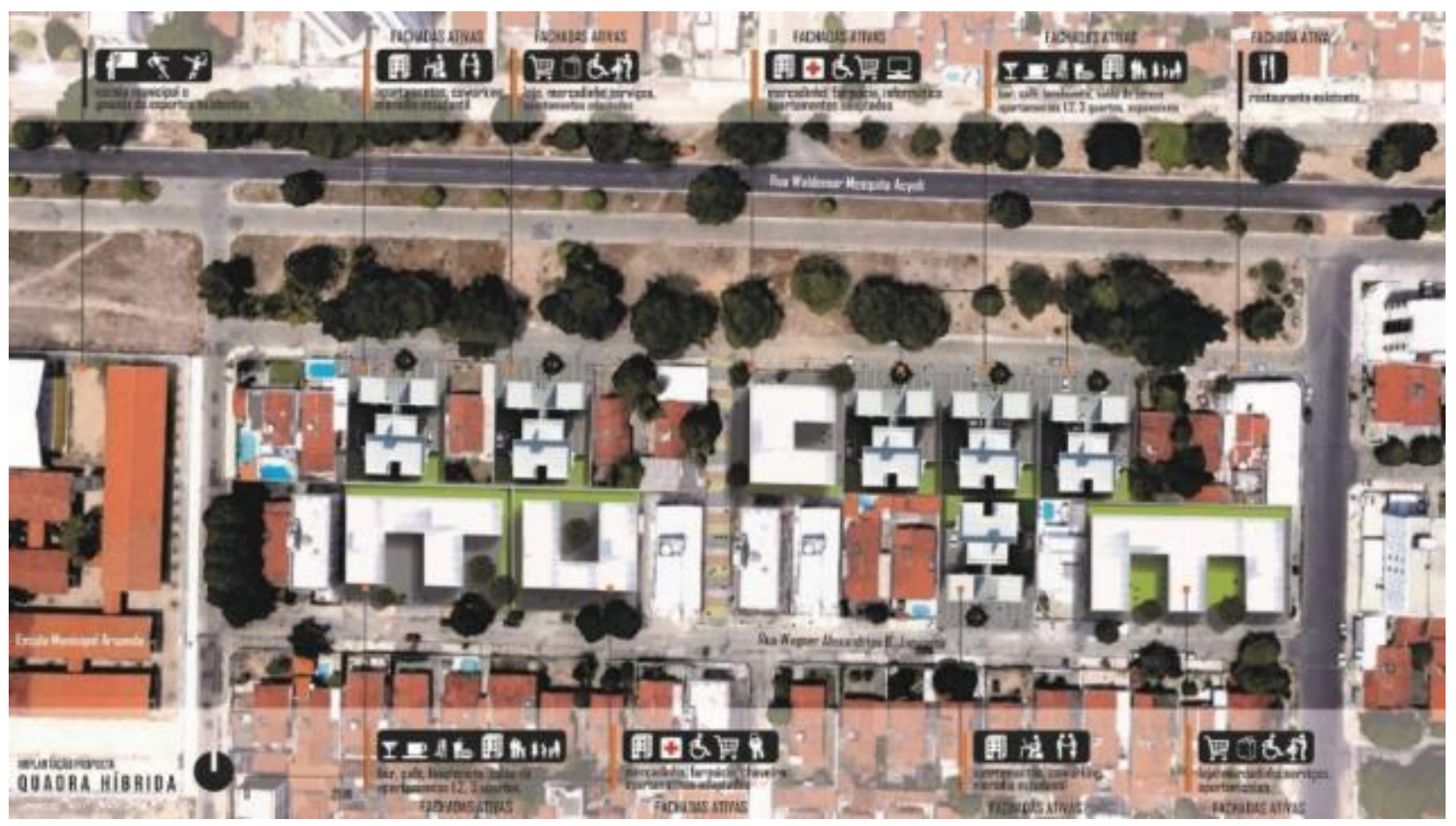

Fonte: Urbanicidade.

\section{A escala do bairro dos Bancários}

No bairro em estudo (e conforme os critérios de escolha das quadras híbridas estratégicas - localização, potencial e influência), pode-se definir pelo menos cinco quadras situadas de forma descentralizada no espaço urbano do bairro, ao alcance de uma caminhada que varia entre $350 \mathrm{~m}$ e $500 \mathrm{~m}$. Acredita-se que com a implementação do uso híbrido/misto nessas quadras, se poderia impulsionar outras transformações na vitalidade urbana, na economia local, nas trocas sociais e na sensação de segurança do bairro, de forma a beneficiar mais de 1800 famílias diretamente e cerca de 2500 famílias indiretamente. Isto porque comércios podem ser criados, rendas geradas, ofertas de empregos, trabalho, lazer, encontros, trocas sociais, empreendedorismo. Juntos com os espaços públicos e comunitários (praças, campos de esportes, associações de bairro), as quadras híbridas podem contribuir decisivamente para a animação urbana e qualidade de vida tão almejada pelos moradores. Ela - a quadra híbrida - é uma relevante ferramenta no processo de planejamento de bairro que pode ser incorporada ao Plano Diretor Municipal, por ora em revisão. 
Figura 19: Mapa dos Bancários e a localização das quadras híbridas propostas (em destaque). Influência no entorno pelo poder catalisador das transformações positivas no bairro.

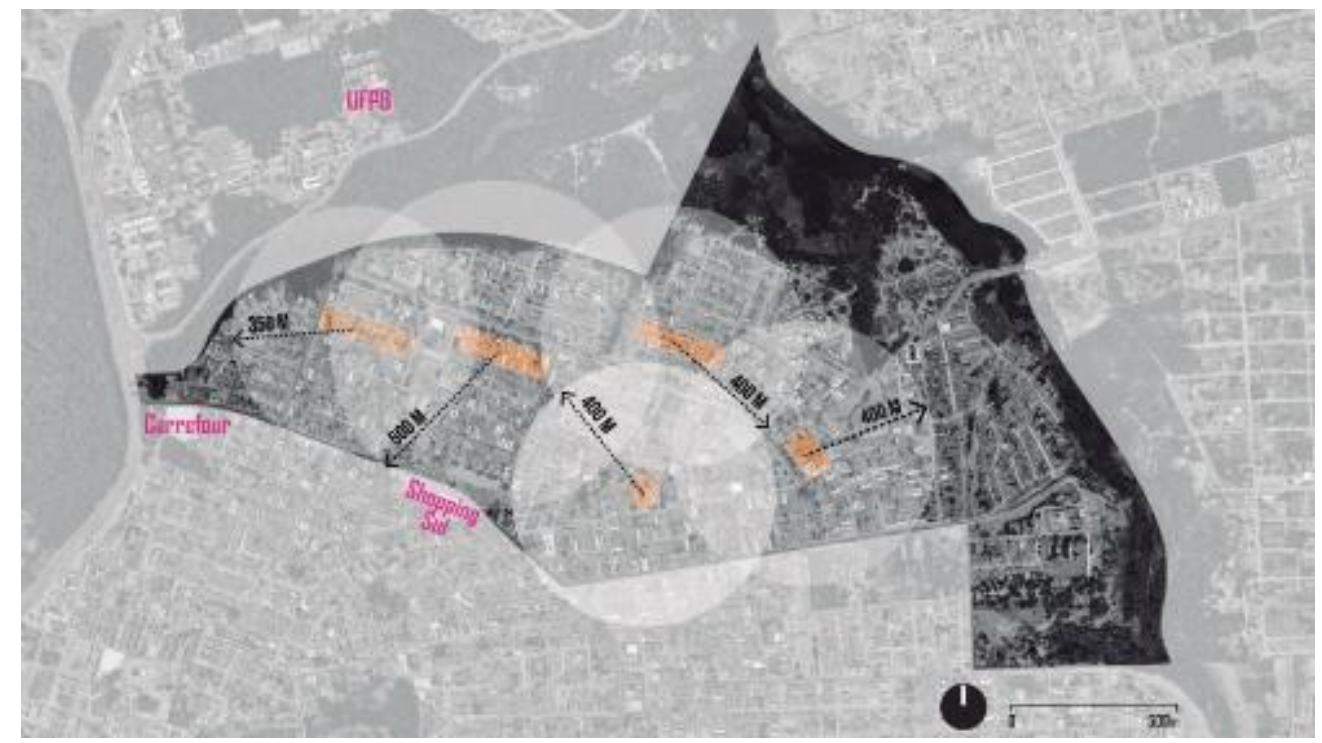

Fonte: Urbanicidade.

\section{Cenários}

Foram elaborados cenários virtuais para ilustrar de forma mais compreensível ao público leigo a viabilidade da proposta. Os edifícios híbridos de quatro pavimentos são formados por dois blocos conectados por passarelas. Possuem no pavimento térreo comércios que dialogam com as calçadas, e na parte posterior, apartamentos de $50,00 \mathrm{~m}^{2}$ de dois quartos com possibilidade de expansão para mais dois quartos. Diversidade tipológica com apartamentos de 01, 02 e 03 quartos é outra característica espacial na escala privada dos apartamentos, além da expansibilidade prevista na proposta. As áreas dos apartamentos variam de $50,00 \mathrm{~m}^{2}$, $60,00 \mathrm{~m}^{2}$ podendo alcançar até $82,00 \mathrm{~m}^{2}$. Nos pavimentos superiores do bloco voltado para a fachada frontal, é sugerida moradia estudantil pelo fato dos Bancários situar-se próximo da Universidade Federal da Paraíba - UFPB e do Centro Universitário de João Pessoa - Unipê. Coworking com flexibilidade de layout é outra opção que busca incentivar empreendedorismo e os negócios próximos das moradias.

Figura 20 e 21: Cenários virtuais com vista frontal e lateral do edifício de uso híbrido. No térreo, os comércios dialogam com a calçada. No último pavimento, entre os apartamentos de 01 , terraço para convivência e eventos.
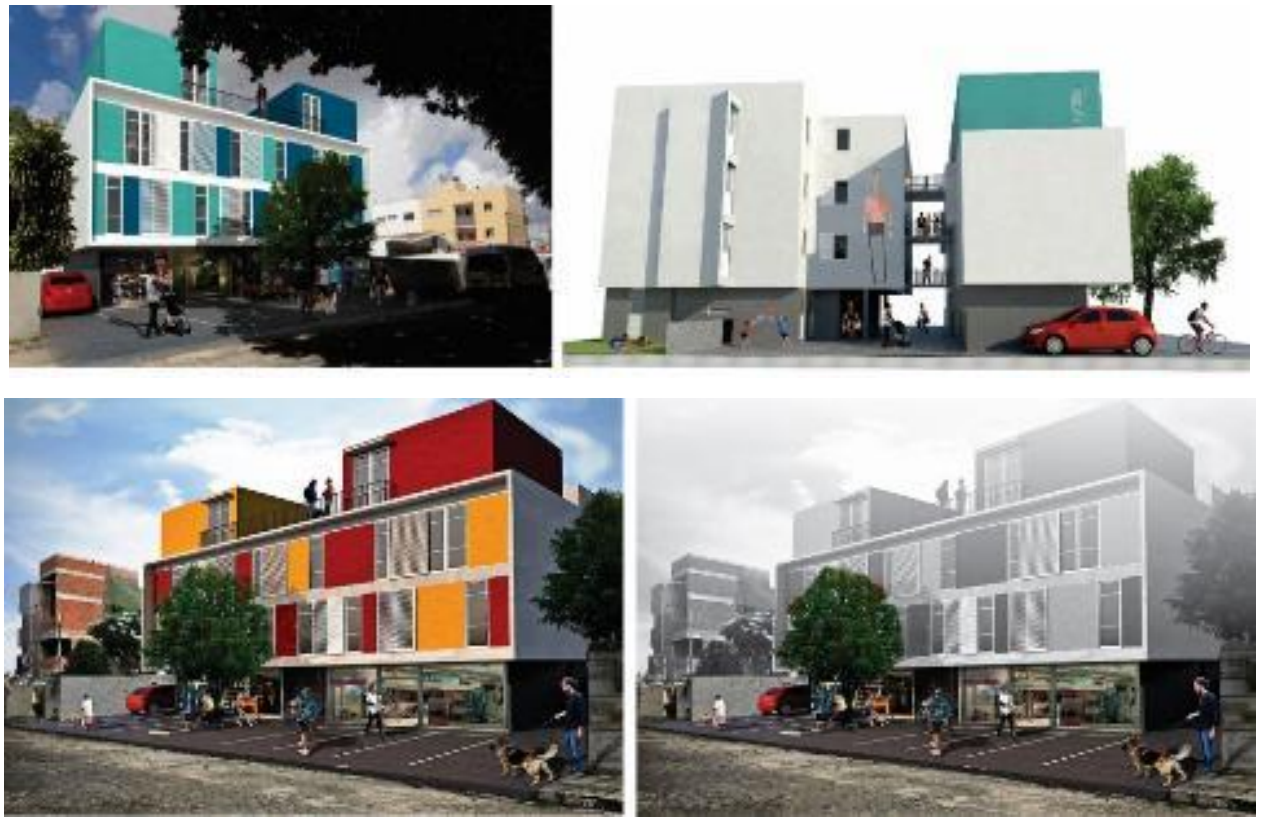

Fonte: Urbanicidade. 
Outro questionamento do recuo frontal foi elaborado, propondo a substituição das vagas de veículos particulares por mesas de apoio para lanchonetes, bares, estimulando as pessoas a tomar um café, um suco, ou um bate papo vendo a vida passar, proporcionando uma relação mais amigável com a cidade. Nota-se também o banco sob árvore como mais uma gentileza urbana prevista.

Figura 23: Outra investigação da composição arquitetônica na quadra. Relação mais amigável com a cidade. Nota-se também o banco sob árvore como mais uma gentileza urbana.

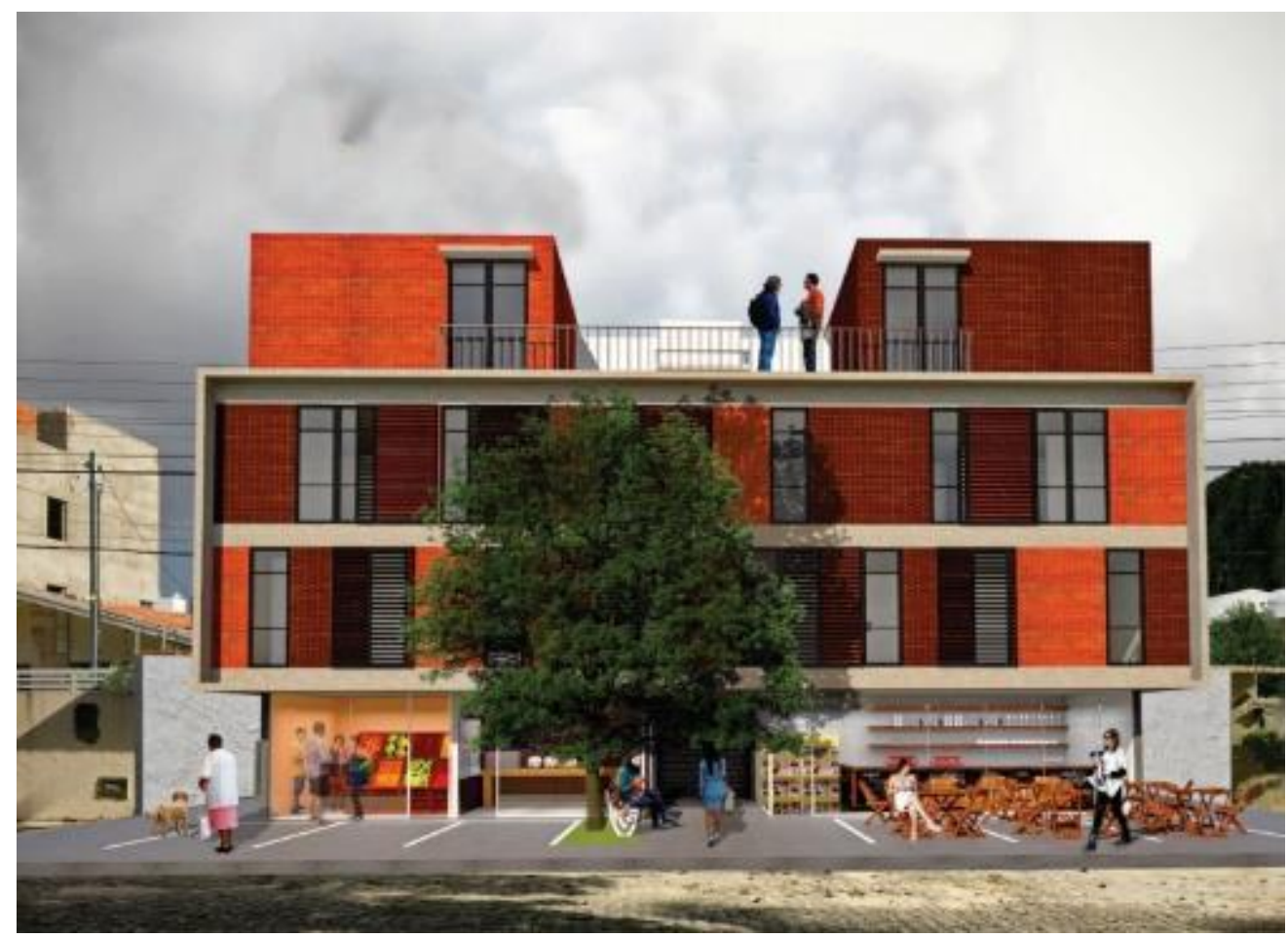

Fonte: Urbanicidade.

\title{
6 CONSIDERAÇÕES FINAIS
}

\begin{abstract}
...com o passar dos anos e com a popularização do automóvel, ficou clara a necessidade de uma norma para regularizar a guarda de veículos particulares nos edifícios. A solução dada foi a regulamentação de pavimentos garagens nas edificações (NÓBREGA, 2014, p.66).
\end{abstract}

O estudo aqui apresentado entende que a forma urbana interfere no comportamento social. No caso específico do bairro, sugere que as mudanças nas quadras dos Bancários sejam realizadas de forma gradual, considerando a simulação dos cenários hipotéticos enquanto instrumento fundamental para revisão da legislação urbanística e para a humanização dos espaços. Para ilustrar, e possivelmente sensibilizar os gestores e o setor privado, foram utilizadas investigações espaciais como ferramentas para demonstrar hipoteticamente uma alternativa ao que vem sendo construído. Aponta que há outras formas de organização espacial combinando tipologias de uso misto (habitacional, comercial e serviços) com as necessidades diárias dos moradores, conforme conceitos de cidade compacta e centralidades urbanas. Os estudos mostrados não têm a pretensão de afirmar a melhor solução, mas são notórias as diferenças entre a situação atual e a situação proposta, embora com necessidade de ser melhor discutida de forma mais ampla.

As construções do espaço privado, que representam grande parcela do solo urbano, podem ser viabilizadas em harmonia com o espaço público, sendo mais atraentes para as trocas sociais e gentis para com a cidade, sem abdicar do ato de morar com qualidade. Por isso, é possível demonstrar que não é incompatível fazer operações urbanas entre agentes do mercado imobiliário e as noções do bom urbanismo. Danosas são as legislações inadequadas que provocam o "desenho das quadras fechadas" e gestores negligentes serem uns dos responsáveis pela cidade hostil e hermética. O fazer urbano mais humano perpassa inevitavelmente pela 
mudança na legislação, e as simulações espaciais e os estudos espaciais aqui investigados podem auxiliar a aprofundar essa discussão (LIMA, 2017).

É possível utilizar os recursos das simulações espaciais como instrumentos de sensibilização e informação para os moradores da cidade. Atualmente se conhecem muito pouco boas práticas urbanas, de espaços públicos com desenho urbano qualificados, da moradia próxima das facilidades urbanas. Isso porque a nossa cidade é fruto do zoneamento dogmático que privilegia o lote fechado, o uso monofuncional, a mistura de usos só nas vias axiais principais, e com alto custo do valor da terra e dos imóveis. Assim, a sociedade aceita tal condição do ato de morar como sendo refém da cidade capitalista, sem ao menos conhecer outras formas melhor para se viver porque há um predominante analfabetismo urbano.

Para reversão deste quadro, em que as tipologias edilícias nos bairros isolam as pessoas em prédios fechados por muros nas quadras dos bairros, com crescente sensação de insegurança presentes nas famílias, e vias cada vez mais sendo ocupadas por veículos particulares, o poder executivo, na condição legal de gerenciar e disciplinar o desenvolvimento urbano, pode capitanear as mudanças no marco legal do zoneamento da cidade, como política pública de regulamentação do disciplinamento do uso e ocupação do solo tanto no bairro em estudo (Bancários), quanto em outros com a mesma tendência de verticalização sem planejamento no território de João Pessoa-PB. Neste sentido, é preciso articular tal prerrogativa no Plano Diretor da Cidade, criando um Plano de Bairro estratégico capaz de aproximar as mudanças espaciais ocorridas nas quadras, das necessidades cotidianas da população.

O estudo apresentado aponta caminhos para serem debatidos com a população usuária frente a um quadro preocupante de adensamento e verticalização já verificados na paisagem do bairro. É uma reflexão sobre os danos que o parcelamento do solo hermético repercute no espaço urbano derivado de legislações urbanísticas antiquadas. Acredita-se ser oportuna essa revisão da forma de morar no momento em que o PD da capital paraibana vem sendo revisado, embora de forma não participativa. Por fim, verifica-se que as mudanças sugeridas nas quadras, podem ser consolidadas desde que com planejamento e incorporadas na legislação urbanística (Plano Diretor e lei de uso e ocupação do solo).

\section{REFERÊNCIAS}

ACIOLY, C.; DAVIDSON, F. Densidade Urbana: um instrumento de planejamento e gestão urbana. Rio de Janeiro. Mauad. 1998.

CAMPOS FILHO, C. M. Reinvente seu bairro: caminhos para você participar do planejamento de sua cidade. São Paulo: Ed.34, 2003.

DANTAS, M. G. A. Planejamento Urbano e Zoning. 1.ed. João Pessoa. Editora Universitária/ UFPB. 2003.

FIGUEROA, M. Habitação coletiva e a evolução da quadra. Vitruvius, Arquitextos. Texto Especial 357, fevereiro de 2006. Disponível em < http://www.vitruvius.com.br/revistas/read/arquitextos/06.069/385> Acesso em: 17 out de 2017.

GEHL, J. Cidades para pessoas. São Paulo, Perspectiva, 2013.

JACOBS, J. Morte e Vida das Grandes Cidades. 3. ed. São Paulo> Martins Fontes, 2011.

LAMAS, J. M. Ressano Garcia. Morfologia Urbana e Desenho da Cidade. Lisboa: Fundação Calouse Gulbenkian, 2007.

LEITE, C. Instrumentos Urbanos Inovadores. Revista Arcoweb, 2016. Disponível em: https://www.arcoweb.com.br/noticias/artigos/carlos-leite-instrumentos-urbanos-inovadores. Acessado em 04 de Abril de 2018.

LIMA, M. A. S.; ISMAEL, L. Desenhando a quadra híbrida no cotidiano dos bairros. Revista Projetar. V.2. N.2. agosto, 2017.

LIMA, M. A. S. Comentários na Página do Fórum Plano Diretor Participativo. Facebook, 06-10-2018.

MAGALHÃES, S. Estratégias projetuais na arquitetura brasileira. Arkhé: Revista de arquitetura e urbanismo. V.2, ItajaíSC. Ed. da Universidade do Vale do Itajaí, 2015.

NÓBREGA, M. L. C.C. "Por um espaço público cidadão: o encontro do edifício com a rua". Recife: Publicações SENGE, 2014.

ROGERS, R. Cidades para um pequeno planeta. Barcelona, Editora Gustavo Gili, 1997, 
SILVA, G. J. A.; Silva, S. E.; Nome, C. A. Densidade, dispersão e forma urbana. Dimensões e limites da sustentabilidade habitacional. Arquitextos - São Paulo. 189.07 urbanismo ano 16, fev. 2016. Disponível em : http://www.vitruvius.com.br/revistas/read/arquitextos/16.189/5957. Acessado em outubro 2017.

SPECK, J. Cidade Caminhável. Tradução Anita Dimarco, Anita Natividade. 1.ed. São Paulo. Perspectiva, 2016.

\section{NOTAS}

${ }^{1}$ Marco Antonio Suassuna Lima, membro fundador do grupo Urbanicidade, graduação em Arquitetura e Urbanismo pela Faculdade de Arquitetura e Urbanismo de Pernambuco (1998) e mestrado em Desenvolvimento e Meio Ambiente pela Universidade Federal da Paraíba (2004). Professor adjunto do Centro Universitário de João Pessoa (Unipê) e da Universidade de ciências sociais aplicadas PB (Unifacisa). Palestrante no XX Congresso Brasileiro de Arquitetos (2014) no Eixo Temático Habitação de Interesse Social. Atuou como assessor técnico na Secretaria Municipal de Habitação de João Pessoa -PB (2006 - 2009). Vice-presidente do IAB-PB, 20102011. Foi diretor da Diretoria de Controle Urbano (DCU) da Secretaria Municipal de Planejamento (SEPLAN) 2013, Prefeitura Municipal de João Pessoa-PB.

${ }^{2}$ Lucio Ismael Lacerda Jr, Arquiteto e Urbanista graduado pelo Centro Universitário de João Pessoa (Unipê) em 2013, especialista em Arquitetura e Cidade pela faculdade UnyLeya - DF em 2016.

${ }^{3} \mathrm{O}$ urbanicidade é um movimento coletivo e independente que pensa as cidades paraibanas de forma propositiva, e foi criado em 2015 por um grupo de arquitetos e urbanistas, artistas, geógrafos, voluntários.

As imagens tridimensionais da proposta foram produzidas pelos membros da equipe do movimento "Urbanicidade": Bárbara Meurer, Renê Venâncio e Sávio Vale (graduandos de arquitetura e urbanismo do Unipê).

NOTA DO EDITOR (*) O conteúdo do artigo e as imagens nele publicadas são de responsabilidade do(s) autor(es). 